Article

\title{
Thermal Performance Assessment of Flexible Modular Housing Units for Energy Independence Following Disasters
}

\author{
Beungyong Park ${ }^{1, *(\mathbb{D})}$, Jinkyun Cho ${ }^{2, *(\mathbb{D})}$ and Yongdae Jeong ${ }^{1}$ \\ 1 Energy Division, KCL (Korea Conformity Laboratories), Jincheon 27872, Korea; jyd@kcl.re.kr \\ 2 Department of Building and Plant Engineering, Hanbat National University, Daejeon 34158, Korea \\ * Correspondence: bypark@kcl.re.kr (B.P.); jinkyun.cho@hanbat.ac.kr (J.C.)
}

Received: 19 August 2019; Accepted: 1 October 2019; Published: 9 October 2019

\begin{abstract}
An investigation was conducted into temporary modular housing for use in disaster areas to assess the feasibility of energy independence. Flexible modular units have been proposed as a temporary housing solution in disaster areas, as they can be deployed in combination with energy units across a wide range of environments. A dynamic energy simulation was used to examine the heating/cooling requirements and the potential photovoltaic power generation of such modular housing in an East Asian climate. This was used to assess the potential for energy independence. The building performance was analyzed based on measurements of airtightness, insulation performance, and thermal bridge phenomena taken from mock-up modular housing. According to the wall assembly method, it was confirmed that the airtightness performance was poor. Further investigations explored the possibility of reducing the annual heating/cooling loads by improving the airtightness, which would contribute to greater energy independence. In general, the specific housing needs of different victim groups can easily be satisfied through the application of different modular unit combinations.
\end{abstract}

Keywords: modular housing; disaster; energy independence; energy load; solar photovoltaic; airtightness

\section{Introduction}

In recent years, the frequency of disasters has sharply increased worldwide [1,2]. Disasters can negatively affect an individual's life, health, and property and can also have national consequences in terms of the population, economy, and infrastructure [3]. In general, disasters can be categorized as natural or social disasters. According to worldwide disaster statistics from 2017, natural disasters included cold waves and heavy snowstorms in Europe; 81 tornadoes in the United States and a large forest fire in California; and heavy snowfall, typhoons, and earthquakes in Japan [1,2]. In South Korea, disasters such as cold waves, heat waves, tropical nights, and typhoons occur frequently. Furthermore, forest fires, fires in densely concentrated buildings, and collapsing buildings represent significant threats, as they have the potential to cause significant loss of life or property. For example, on 15 November 2017, apartment buildings were destroyed and many people lost their homes due to an earthquake in the Pohang area. When disasters occur, it is necessary to provide food and temporary housing quickly to victims. Previously, local public facilities such as schools, religious buildings, and public amenities have often been used as temporary shelters.

In other situations where it is difficult to provide temporary housing, portable facilities such as emergency tents and containers have been used. Another type of temporary housing can be provided by modular buildings. Modular buildings are made from lightweight materials and they are easy to carry and assemble; this makes them suitable for use as temporary shelter. Accordingly, 
modular buildings have been used in Japan, the United States, and Europe [4,5]. Modular housing has been studied for decades [4-10]; for example, Kamali and Hewage analyzed its advantages and limitations [6]. Other research has examined passive energy use, energy simulations, and phase change materials (PCMs) [7-10]. However, in disaster situations, infrastructure facilities such as electricity, water, and gas may not be available, which represents a serious limitation for modular housing. Therefore, it is necessary to consider the requirements of temporary housing and design solutions that enable temporary residence without the need for such infrastructure.

In this study, the temporary modular housing used in disaster areas was investigated in order to assess the feasibility of energy independence. The results of this investigation were then used to propose a suitable design for temporary housing using flexible modular units. These modular units are useful in disaster situations, as they can be used in many different combinations alongside energy units. This means that the specific housing needs of different victim groups can easily be satisfied. We began by investigating the modular buildings currently being used as temporary housing in disaster situations, both domestically and abroad. We then evaluated the energy requirements of these buildings based on a mock-up model. Thermal insulation, airtightness, and condensation were targeted as major factors that affect the energy performance. Finally, the heating/cooling requirements and the potential for energy independence were assessed based on improvements in airtightness and the installation of solar photovoltaic (PV) systems.

\section{Theoretical Discussion and Case Studies}

According to Smith [11], industrialized housing has developed based on demand and available construction techniques. During the 16th and 17th centuries, Great Britain colonized much of the world, including India, the Middle East, Africa, Canada, and the United States. As a result, rapid construction was required in these areas. To meet this demand, components (wooden kits) were manufactured in England then transported worldwide via ships. This was first recorded in 1624. Later, on-site methods, where components are assembled at the construction site, and out-site methods, where the components are assembled in a factory before transportation, were developed; this is called the modularization method. Modular structures can be used for commercial and residential applications, which may be temporary or permanent. Modular commercial buildings include temporary structures such as construction site trailers, mobile classrooms, communication pods, and exhibition rooms as well as permanent structures such as dormitories, healthcare facilities, hotels, government buildings, and schools. The overseas modular building market has been led by advanced countries such as those in Europe, Japan, the United States, Canada, and Australia. The United Kingdom has the largest market for modular buildings, which make up $2.1 \%$ of the total construction market. In Korea, the market is estimated to be worth between 1.34 and $\$ 4$ trillion [12].

\subsection{Literature Review}

In South Korea, studies on disaster relief housing are mostly related to architectural planning, such as planning requirements for temporary housing facilities, construction methodology, and functional demands. Kim et al. examined different types and plans for temporary housing relief as architectural countermeasures for disaster refugees [13]. In particular, they classified and examined time-series-type structures and construction methods and then proposed a relief housing system suitable for open system modular housing. Moon et al. mentioned that temporary housing is affected by climate, structure, material, and duration of use, with structure being the most important factor. They demonstrated that fixed and portable housing can be categorized according to the structural characteristics [14]. The relief housing development by Lim et al. can be seen as a representative study on practical development [15]. They developed relief housing using standard elevation modules. The pilot application was examined using a subway station as a temporary shelter. Wang et al. proposed a horizontal expansion method based on joint development with modular-method-applied temporary housing [16]. Through the design and mock-up module fabrication, they addressed the 
need for additional techniques to be developed with respect to reinforcing airtightness when joining, horizontal leveling when joining units, and the locking method between units. Similarly, disaster relief housing plans and temporary modular housing have been developed, but they are limited by the development of technical plans, structural aspects, and the joining of modules. In fact, few studies have addressed the thermal insulation and environmental performance aspects of housing development, which is necessary to understand the energy independence performance and the need for new and renewable energy generation and storage systems.

Modular housing for use in disaster areas should be able to provide the energy required by residents by utilizing elemental technologies such as solar panels, even in areas where the supply infrastructure is not available. Many previous studies [17-20] have been conducted on net zero energy buildings and energy-independent buildings utilizing passive and active designs. Wind energy systems and PV panels are actively used for zero energy buildings and the energy savings achieved using active elements have been compared and analyzed. Aldegheri et al. demonstrated that it is possible to achieve energy production equivalent to $43 \%$ of the annual energy consumption of demonstration houses with building-integrated concentrating photovoltaics (BICPVs) [19]. It is important for modular housing to be suitable for various climates. Zubair et al. showed that the cooling load could be reduced by $12.3 \%$ by installing a PV panel on net present cost(NPC)-based roof, even in hot climates [20].

\subsection{Domestic and Overseas Modular Housing for Disaster Response}

Table 1 summarizes the existing research for modular disaster relief housing in South Korea and overseas in terms of the climate, shape, and vertical/horizontal expansion [15,21-27]. Typical shapes include modules, containers, a combination of containers and tents, assembly type, and box unit type. Each of these is classified as either horizontal or vertical space expansion type due to structural differences based on the shape characteristics. In situations where the structures are not secured to make them stable, horizontal expansion is common; in contrast, modular and container-type buildings have a steel structure that facilitates vertical expansion. Features such as the finish and design of the exterior material are selected according to the local climate.

South Korea type A has a modular design which facilitates both horizontal and vertical expansion. The units (e.g., living room and utility units) can be configured depending on the number of people in the household. It has a steel structure, and steel panels are used for the exterior material. USA type A is designed so that the thermal insulation can be customized according to the weather. In addition, solar panels are used to supply electricity and water can be stored in a water module capable of collecting rain water. USA type B is a vertically expandable combination of container- and tent-type structures. The rooms can easily be divided and the tents can be converted to increase the space for kitchens, bathrooms, and storage. It can accommodate up to two households based on a family of four people. USA type $C$ is a modular prefabricated system. It is not suitable for horizontal or vertical expansion but is designed to withstand storms. USA type D is an assembly type suitable for both horizontal and vertical expansion. It is easy to assemble, can be expanded without tools, and is suitable for uneven terrain. Aluminum insulation panels are also used, which means that it can easily be reused or expanded; this makes it suitable for temporary classrooms or offices as well as housing. Japan type A is a container-based system suitable for horizontal expansion, which is achieved by connecting two containers. Once they have been used as temporary housing following earthquakes or tsunamis, they can be converted to permanent structures. Japan type B is another container-based system, but it allows both horizontal and vertical expansion. It is suitable for sloped or narrow areas of land and can be constructed up to three stories high if the basic container area is secured. The container frame means that the structure has excellent internal performance, so it can be used on a permanent basis. Furthermore, since expansion is easy, it can be adapted to various sizes depending on the number of people that need to be accommodated. Europe type A has an assembly-type structure that facilitates horizontal expansion. Since each material is controlled, installation is easy and expansion is simple. It is designed so that the indoor temperature can easily be maintained by reflecting solar heat according 
to the climate. As a result of a survey, it is focused on the convenience of installation and structural safety. Although solar panels are technically employed, the details regarding capacity and installation type are difficult to confirm.

Table 1. Case study of modular housing [15,21-27].

\begin{tabular}{|c|c|c|c|c|}
\hline \multirow{2}{*}{ Types } & Type & Extend Function & \multirow{2}{*}{ Description } & \multirow[t]{2}{*}{ Images } \\
\hline & Climate & Area & & \\
\hline \multirow[t]{2}{*}{ Korea-A } & Modular & $\begin{array}{l}\text { Horizon }(\mathrm{O}) \\
\text { Vertical }(\mathrm{O})\end{array}$ & \multirow[t]{2}{*}{ Solar panel } & \\
\hline & Temperate rainy & $\begin{array}{l}9 \mathrm{~m}^{2}, 18 \mathrm{~m}^{2} \\
27 \mathrm{~m}^{2}, 36 \mathrm{~m}^{2}\end{array}$ & & \\
\hline \multirow[t]{2}{*}{$\mathrm{USA}-\mathrm{A}$} & Prefab & $\begin{array}{l}\text { Horizon }(\mathrm{O}) \\
\text { Vertical }(\mathrm{X})\end{array}$ & \multirow[t]{2}{*}{$\begin{array}{l}\text { Solar panel, rain water } \\
\text { harvesting }\end{array}$} & \\
\hline & All climate & $47 \mathrm{~m}^{2}$ & & \\
\hline \multirow[t]{2}{*}{ USA-B } & Container/tent & $\begin{array}{l}\text { Horizon }(\mathrm{O}) \\
\text { Vertical }(\mathrm{X})\end{array}$ & \multirow[t]{2}{*}{$\begin{array}{l}\text { Solar panel, rain water } \\
\text { harvesting }\end{array}$} & \\
\hline & Mediterranean & - & & \\
\hline \multirow[t]{2}{*}{$\mathrm{USA}-\mathrm{C}$} & Prefab & $\begin{array}{l}\text { Horizon }(X) \\
\text { Vertical }(X)\end{array}$ & \multirow[t]{2}{*}{$\begin{array}{l}\text { Solar panel, passive } \\
\text { cooling, natural ventilation }\end{array}$} & \\
\hline & Subtropical & $13.9 \mathrm{~m}^{2}$ & & \\
\hline \multirow[t]{2}{*}{ USA-D } & Prefab & $\begin{array}{l}\text { Horizon }(\mathrm{O}) \\
\text { Vertical }(\mathrm{O})\end{array}$ & \multirow[t]{2}{*}{ Solar panel } & \\
\hline & Subtropical & - & & \\
\hline \multirow[t]{2}{*}{ Japan-A } & Container & $\begin{array}{l}\text { Horizon }(X) \\
\text { Vertical }(X)\end{array}$ & \multirow[t]{2}{*}{-} & \\
\hline & Temperate rainy & $24 \mathrm{~m}^{2}$ & & \\
\hline \multirow[t]{2}{*}{ Japan-B } & Container & $\begin{array}{l}\text { Horizon }(X) \\
\text { Vertical }(X)\end{array}$ & \multirow[t]{2}{*}{-} & \\
\hline & Temperate rainy & $\begin{array}{l}12.3 \mathrm{~m}^{2}, 14.1 \mathrm{~m}^{2} \\
29.4 \mathrm{~m}^{2}, 42.6 \mathrm{~m}^{2}\end{array}$ & & \\
\hline \multirow[t]{2}{*}{ EU-A } & Prefab & $\begin{array}{l}\text { Horizon }(X) \\
\text { Vertical }(X)\end{array}$ & \multirow[t]{2}{*}{ Solar panel } & \\
\hline & Ocean climate & $17.5 \mathrm{~m}^{2}$ & & \\
\hline
\end{tabular}

\subsection{Characteristics of Developed Modular Housing}

Figure 1 shows a conceptual diagram for energy independence of flexible housing as part of a disaster response. It is an assembly unit that facilitates expandability via modular houses consisting of modular units that are $(3 \times 3) \mathrm{m}$ in size. Each unit has one of four functions: housing, energy (power supply), water (greywater/sewage), and core (stairs/corridor). The manufacturing process of modular 
units means that they are convenient to move and transport, while their cubic shape makes vertical and horizontal expansion straightforward. Depending on the duration of use, they can be used as temporary or permanent facilities. One set of units is used to build one house and, depending on the area requirements, they may be moved and installed independently. Moreover, the units can be combined and expanded according to functional requirements. To facilitate energy production and storage in situations with no infrastructure, PV systems and energy storage systems (ESSs) are included in the energy unit. The water unit includes a water treatment system which supplies water and recycles rainwater/greywater for domestic use. The air-conditioning, heating, and hot water systems used to maintain the living environment produce energy by consuming electricity. The core unit is used to allow horizontal and vertical movement between the other units.

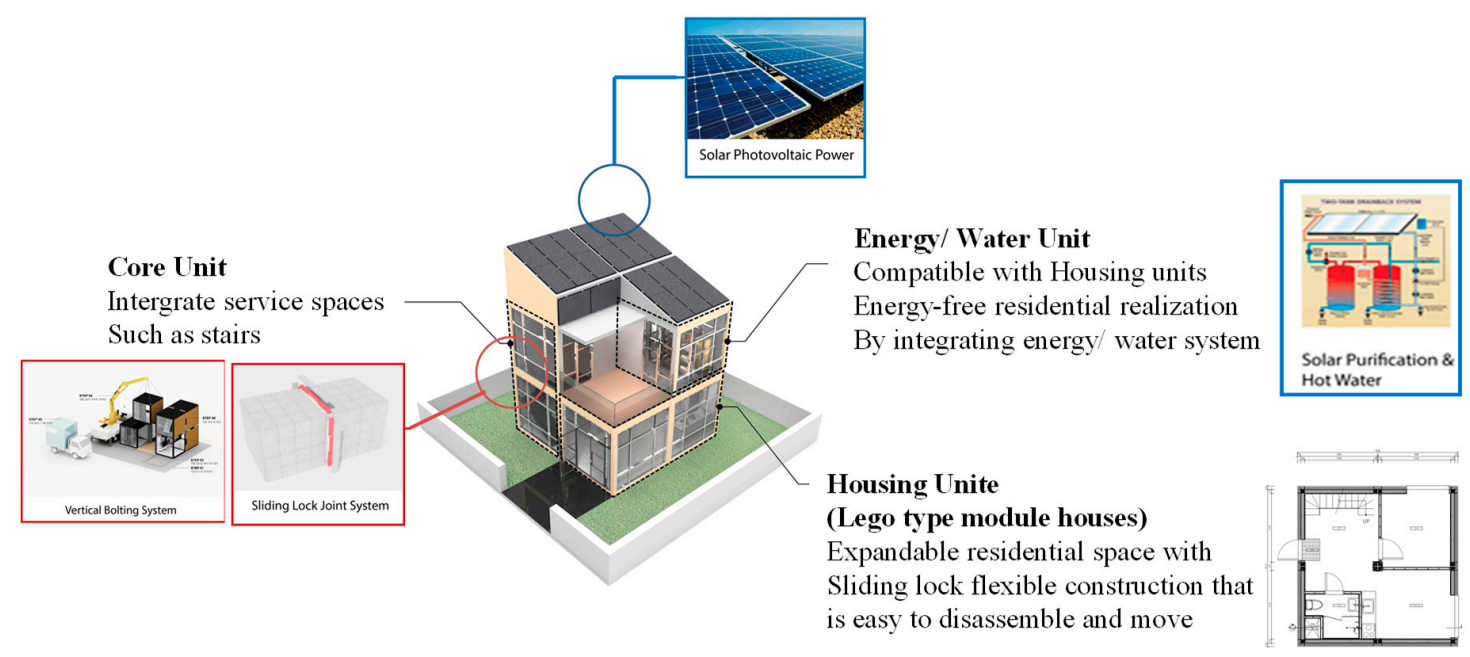

Figure 1. Concept of energy independence of flexible modular housing.

In this study, we employed a TRSNSYS 17 simulation that used a transfer function method to simplify the arduous heat balance method. We conducted mock-up experiments to verify the energy independence of the architecture based on current designs and construction methods. Actual data for insulation and airtightness were used as boundary conditions for the simulation.

\section{Mock-Up Modular Housing}

Figure 2 shows a typical layout for flexible modular housing units. The model represents a two-story, single-family house with a floor area of $72 \mathrm{~m}^{2}\left(65 \mathrm{~m}^{2}\right.$ of air-conditioned area) and an elevation of $5.99 \mathrm{~m}$. It is constructed by assembling eight basic modules measuring $(3 \times 3 \times 3) \mathrm{m}$ and consists of a kitchen, living room, bathroom, and three bedrooms. Figure 3 shows the composition of the walls. From the outside, they consist of a composite panel, thermal insulator, moisture-permeable waterproof sheet, plywood, glass wool, and gypsum board. Once the foundations and columns have been assembled, the wall panels are added, followed by the windows and doors, and finally the interior and exterior materials. The building design meets the insulation criterion (walls less than $0.260 \mathrm{~W} / \mathrm{m}^{2} \cdot \mathrm{K}$, windows and doors less than $1500 \mathrm{~W} / \mathrm{m}^{2} \cdot \mathrm{K}$ ) for energy-saving building design in the central region of Korea [28]. Figure 4 shows the production process for modular housing. Figure 5 shows the explanation of modular joint by sliding lock methods. The coupling between modules uses the prefabricated sliding lock method. After assembling the module, airtight taping and external finishing are performed. 


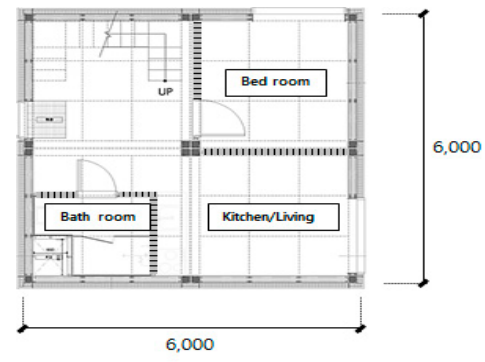

$<1^{\text {st }}$ floor $>$

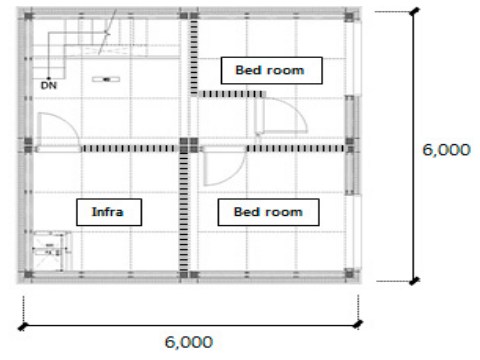

$<2^{\text {nd }}$ floor $>$

Figure 2. Layout of flexible modular housing units.

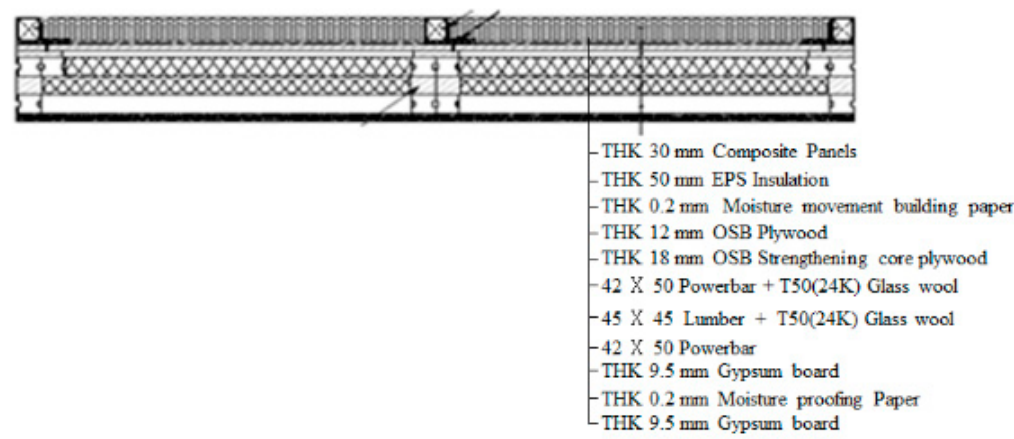

Figure 3. Composition of the walls.

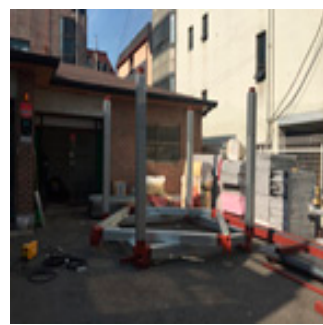

(a)

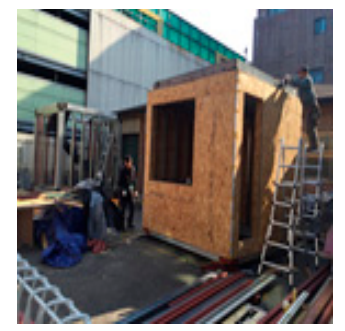

(b)

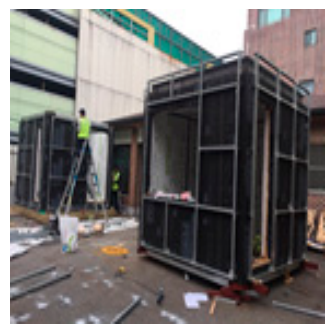

(c)

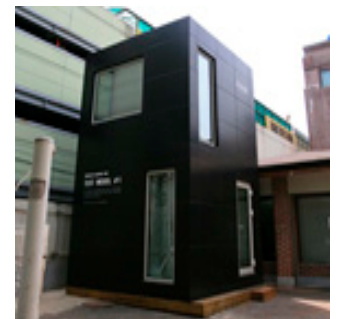

(d)

Figure 4. Manufacturing process of flexible modular housing ((a): Installation of columns, (b): Installation of walls, (c) 1F/2F combination, (d) Finished).

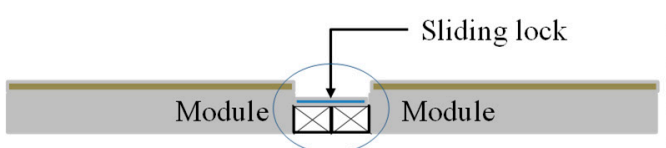

$\checkmark$

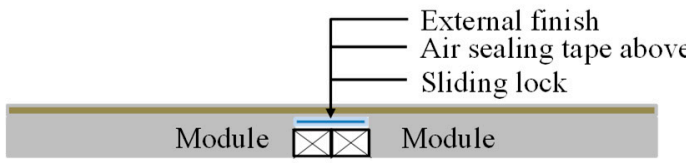

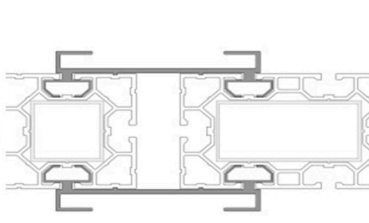

Sliding lock

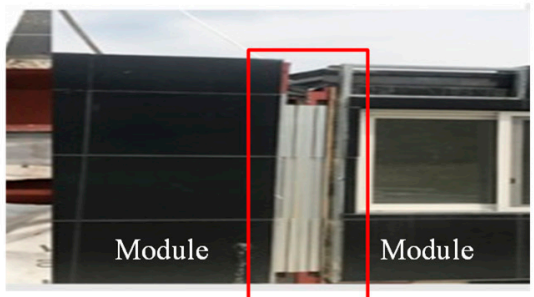

Figure 5. Schematic explanation of modular joint by sliding lock methods. 


\subsection{Test of Building Performance Using Mock-Up}

In Korea, housing is constructed using industrial techniques such as modularization according to the performance and living standard requirements defined by the government. The details of these requirements are given in Appendix 6: The performance and production standards of industrialized housing from Article 13 (performance and production standards of industrialized housing) of the regulation for housing construction standards published by the Ministry of Land, Infrastructure, and Transport in Act 584 [29]. Of these requirements, the airtightness performance, thermal insulation performance, and condensation, which affect energy consumption, are evaluated in this section.

Table 2 shows the modular housing airtightness and thermal insulation evaluation standards and the condensation prevention requirements. Airtightness was evaluated using "KS L ISO 9972: thermal insulation and building airtightness measurement-fan pressurization method" [30], and airtightness of 1.5 times/h must be maintained based on a pressure differential of $50 \mathrm{~Pa}$. A Minneapolis blower door device was connected to a door to ensure that there were no leaks at the joint between the device and the building. The parts that affect airtightness, such as the kitchen hood and power outlets, were treated to make them airtight. In the case of thermal insulation, the performance was evaluated according to "KS F 2278: thermal insulation test method for windows and doors" [31], which must conform to the heat loss prevention standards of the local area. The condensation prevention performance was assessed using measurements taken from a condensation prevention performance simulation of the building's structure developed using a program suitable for testing international standards, such as the condensation prevention performance test method ISO 10211 [32]. In this study, we determined whether condensation occurred using the temperature difference ratio (TDR) from ISO 10211. The TDR for the surface temperature of joints and the indoor/outdoor temperature must be 0.20 or less [33]. The TDR equation is given by

$$
\mathrm{TDR}=(\mathrm{Ti}-\mathrm{Tm}) /(\mathrm{Ti}-\mathrm{To})
$$

where Ti, To, and Tm denote the temperature inside, outside, and at the joints, respectively. Moreover, a thermal imaging camera was used to diagnoses thermal bridges at the drywall connection. In order to make the indoor and outdoor temperatures different, an indoor electronic radiant heating system was installed and the temperature difference was adjusted to $10^{\circ} \mathrm{C}$ or greater.

Table 2. Performance standards of industrialized housing.

\begin{tabular}{ccc}
\hline Item & Standard & Requirement \\
\hline Airtightness & KS L ISO 9972 & Airtightness 1.5 times/h, at 50 Pa pressure difference \\
Insulation & KS F 2278 & Suitable for heat loss prevention standard \\
Condensation & ISO 10211 & Temperature difference ratio less than 0.20 \\
\hline
\end{tabular}

\subsection{Simulation Study Cases}

This case study examined the energy independence performance of the proposed model in past disaster areas in East Asia. Figure 6 shows the location of the analysis area and the past disaster status. Chengdu, Dacca, Bangkok, Ulsan, and Sapporo have frequently suffered from disasters and represent areas where disasters are likely to occur in the future. To verify the feasibility of energy-independent operation, we examined the solar PV system and heating/cooling load requirements. Modular housing has the advantage of a short construction period and reduced on-site labor costs through the componentization and the assembly of building materials. However, this construction method can result in challenges around sound insulation, fire resistance, and airtightness. 


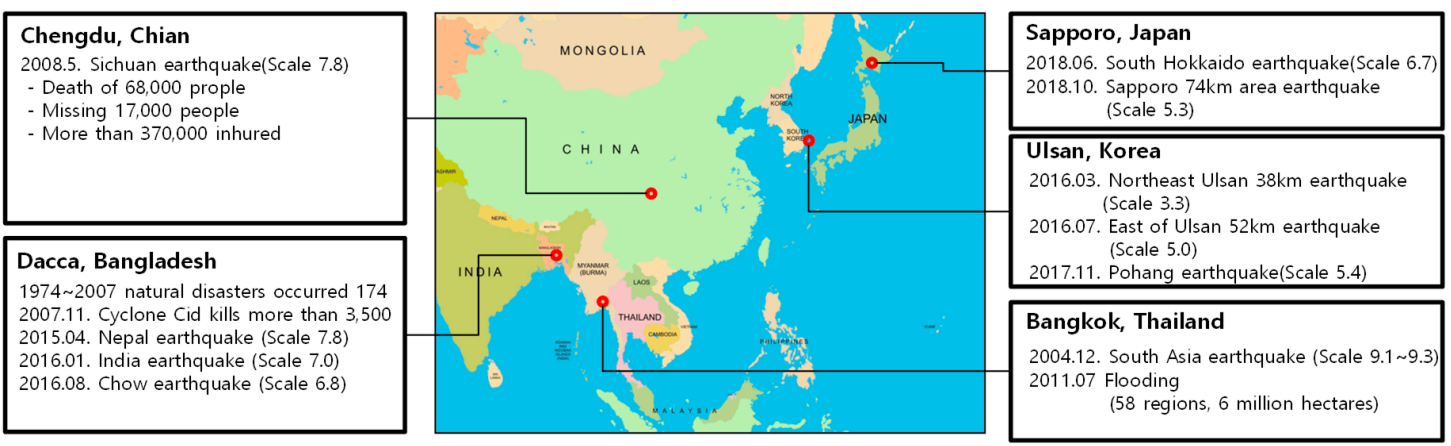

Figure 6. Evaluation of areas and history of disasters.

In this study, airtightness was considered to be important for reducing the load required for construction. The heating and cooling energy load requirements for airtightness were calculated. These simulations were used to assess the thermal characteristics of this modular housing design in different climates as well as their effect on passive technologies such as airtightness and implications for energy independence. The required airtightness and insulation performances of the walls/windows were used as the boundary conditions for the simulation. The detailed simulation conditions are listed in Table 3. Table 4 shows the simulation cases for airtightness, the calculated heating/cooling loads, and the solar PV system installations. Mock-up case 1 (Base) represents the current mock-up level, Case 2 is the wooden house level $9.00 \mathrm{ACH} 50(1 / \mathrm{h})$, Case 3 is the detached house level $3.08 \mathrm{ACH} 50(1 / \mathrm{h})$, and Case 4 is the confidential apartment level $1.80 \mathrm{ACH} 50(1 / \mathrm{h})$. ACH50 is the air changes per hour at a pressure differential of $50 \mathrm{~Pa}$. For the heating analysis, the heating load was less than $22{ }^{\circ} \mathrm{C}, 50 \%$ relative humidity (R.H.) and the cooling load was greater than $26^{\circ} \mathrm{C}, 50 \%$ R.H. It operated continuously when the indoor conditions were outside the thermal set range. For electric energy production, the Type 562 module was used to analyze the power generated by solar panels. Weather data, building model (Type 56), and solar panel type (Type 562) were used in the interpretation. Input variables included regional weather data, solar cell electrical characteristics, and system installation conditions (installation surface and installation orientation angle). For the installation surface, the amount of power generated from the roof and wall installations was examined. The azimuth was considered to be installed on the walls with south and west/east bearings. Through this, it was possible to confirm the most ideal production amount for the solar installation depending on the climate. Finally, the possibility of an energy-free design was confirmed by matching the heating/cooling energy load requirements with the electricity production.

Energy independence rates $(\%)=($ Annual requirement of heating and cooling loads/Solar PV electric generation) $\times 100 \%$

Table 3. Boundary conditions for simulation.

\begin{tabular}{|c|c|}
\hline Weather Conditions & Chengdu, Dacca, Bangkok, Ulsan, and Sapporo (Meteonorm) \\
\hline Gross Floor Area & $\begin{array}{c}72 \mathrm{~m}^{2} \text { (Air-conditioned areas of } 65.3 \mathrm{~m}^{2} / \text { Non-air-conditioned areas } \\
\text { of } 6.7 \mathrm{~m}^{2} \text { ) }\end{array}$ \\
\hline U-Value & Wall $0.180\left(\mathrm{~W} / \mathrm{m}^{2} \cdot \mathrm{K}\right)$, windows $0.996\left(\mathrm{~W} / \mathrm{m}^{2} \cdot \mathrm{K}\right)$ \\
\hline Internal Heat & Four persons (body heat emissions of $100 \mathrm{~W} /$ person, ISO 7730) \\
\hline Set Temperature & Heating set temperature and relative humidity: $22^{\circ} \mathrm{C}, 50 \%$ R.H. \\
\hline (Heating/Cooling) & Cooling set temperature and relative humidity: $26^{\circ} \mathrm{C}, 50 \%$ R.H. \\
\hline Solar Photovoltaic (PV) & Module: TYPE 562/efficiency factor: $16 \%$ Maximum output of $240 \mathrm{~W}$ \\
\hline
\end{tabular}


Table 4. Simulation cases of airtightness and solar PV installation conditions.

\begin{tabular}{cccccc}
\hline Cases & Airtightness & Note & Cases & $\begin{array}{c}\text { Solar PV System } \\
\text { Installation (Slope } \\
\text { Angle) }\end{array}$ & Note \\
\hline Case 1 & 12.13 & Heating and cooling & Case a & Case b & Roof $\left(0^{\circ}\right)$ \\
Case 2 & 9.00 & Wall: South $\left(90^{\circ}\right)$ & Electricity generation \\
Case 3 & 3.08 & requirement load & Case c & Wall: West $\left(90^{\circ}\right)$ & Calculation \\
Case 4 & 1.80 & & Case d & Wall: East $\left(90^{\circ}\right)$ & \\
\hline
\end{tabular}

\section{Results and Discussion}

\subsection{Building Performance}

Table 5 shows the air leakage rate and airtightness performance according to the pressure difference. When a pressure difference of $50 \mathrm{~Pa}$ was applied, the air leakage rate was $426 \pm 6 \mathrm{~m}^{3} / \mathrm{h}$ and the airtightness performance ACH50 was 12.13 1/h. This demonstrates that the airtightness performance $\mathrm{ACH} 50$, which is proposed in the performance and production standards for housing units, does not satisfy the limit of $1.501 / \mathrm{h}$.

Table 5. Results of airtightness evaluation.

\begin{tabular}{cccc}
\hline Item & Standard & Pressure Difference & Results \\
\hline \multirow{3}{*}{ Measure results } & 1 & $29.2 \mathrm{~Pa}$ & $329 \mathrm{~m}^{3} / \mathrm{h}$ \\
& 2 & $24.6 \mathrm{~Pa}$ & $304 \mathrm{~m}^{3} / \mathrm{h}$ \\
& 3 & $20.1 \mathrm{~Pa}$ & $274 \mathrm{~m}^{3} / \mathrm{h}$ \\
& 4 & $15.1 \mathrm{~Pa}$ & $240 \mathrm{~m}^{3} / \mathrm{h}$ \\
Test results & $10 \mathrm{~Pa}$ & $197 \mathrm{~m}^{3} / \mathrm{h}$ \\
& 5 & Leakage $50 \mathrm{~Pa}$ & $(426 \pm 6) \mathrm{m}^{3} / \mathrm{h}$ \\
& \multicolumn{3}{c}{ Airtightness } \\
ACH@50 & $(5.91 \pm 0.60) \mathrm{m}^{3} /\left(\mathrm{m}^{2} \cdot \mathrm{h}\right) @ 50 \mathrm{~Pa}$ \\
& & $12.131 / \mathrm{h}$ \\
\hline
\end{tabular}

Figure 7 shows the relationship between the air leakage rate and the differential pressure. In a housing unit, the structural components are dry and it is difficult to ensure the airtightness performance if airtight construction is not used for the joints. The airtightness of buildings is an important factor for improving their energy performance [34], and many studies on the airtightness of residential housing have been performed in various countries [34-42].

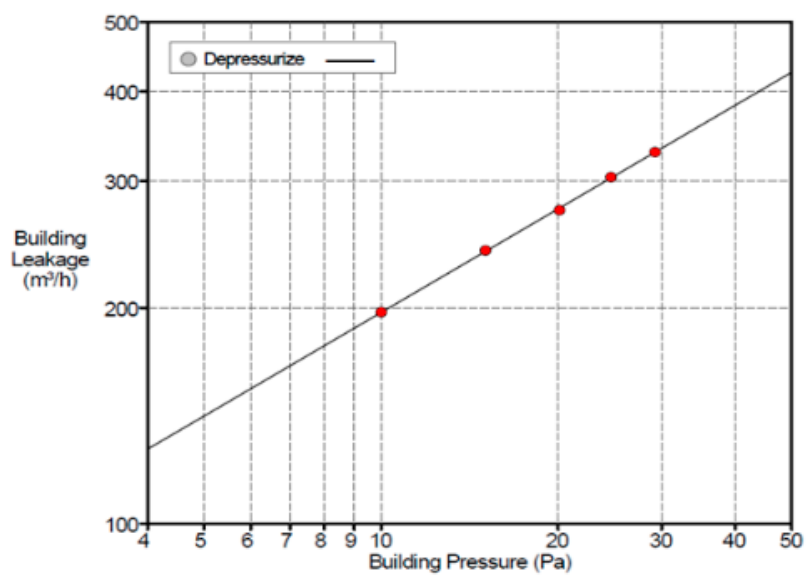

Figure 7. Specification of measurement results.

Figure 8 shows the envelope airtightness of residential housing in Korea and other countries. Korean houses are categorized into light frame (ACH50 3.50 1/h), post and beam (ACH50 2.25-12.30 1/h), 
and cross-laminated timber (ACH50 1.10 1/h) [41]. International housings are categorized into light weight (ACH50 4.91 1/h), cavity wall envelope (ACH50 5.39-14.90 1/h), and precast concreate and timber-framed houses (ACH 1.69 1/h) $[39,40,43]$. Timber housings are categorized into light timber frame (ACH50 3.38-23.50 1/h), post and beam (ACH50 5.91-10.55 1/h), and log house (ACH50 78.68 1/h) [42].

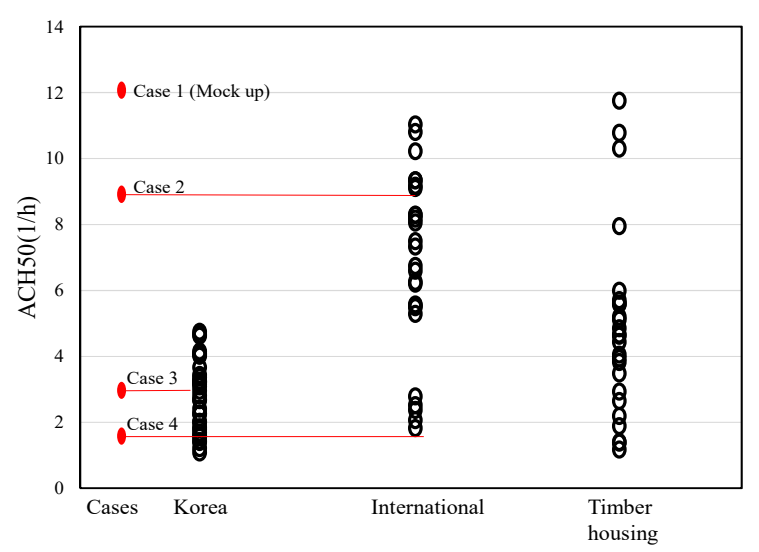

Figure 8. Envelope airtightness of residential housing [34-43].

The modular housing proposed in this study is wooden and has an airtightness of $12.13 \mathrm{1} / \mathrm{h}$ at $50 \mathrm{~Pa}$. Therefore, by improving the airtightness of the modular housing proposed in this study, the energy performance can be increased and refugees will be able to live in residential areas with lower energy production. Kim et al. showed that it is possible to improve airtightness by using spray foam insulation or an air barrier instead of the glass wool mainly used in wooden homes in Korea [41]. Kim et al. also showed that inserting a polyethylene film between the gypsum boards could improve the airtight performance of a wooden house by $50 \%$ [42].

The thermal transmittance of the walls, according to KS F 2278, was found to be $0.180 \mathrm{~W} /\left(\mathrm{m}^{2} \cdot \mathrm{K}\right)$. When a separate test report was completed (test report number: RK2014-0103), the thermal transmittance of the windows was $0.996 \mathrm{~W} /\left(\mathrm{m}^{2} \cdot \mathrm{K}\right)$. This meets the required standard when compared with the standard for the exterior walls of living rooms $\left(0.240 \mathrm{~W} /\left(\mathrm{m}^{2} \cdot \mathrm{K}\right)\right.$ or less $)$ and windows/doors $\left(1.500 \mathrm{~W} /\left(\mathrm{m}^{2} \cdot \mathrm{K}\right)\right.$ or less) of nonapartment houses in the Central Region II of South Korea, as stated in the Energy Saving Standard for Buildings (notification no. 2017-881 of the Ministry of Land, Infrastructure, and Transport).

The diagnosis of thermal bridges was conducted using a thermal imaging camera with an outdoor temperature of $(7.8 \pm 0.3)^{\circ} \mathrm{C}$, an indoor temperature of $(26.3 \pm 1.8)^{\circ} \mathrm{C}$, and indoor/outdoor temperature difference of $(18.5 \pm 1.5)^{\circ} \mathrm{C}$, which was a condition where thermal bridges may occur. Figure 9 shows the results for part of the housing unit. It was confirmed that a thermal bridge occurred at the joints between the wall modules and at the edges. To evaluate the occurrence of condensation, a program is provided in ISO 10211; however, we performed the calculation using the measured values with the TDR equation. The required value for the condensation evaluation standard for industrialized houses is a TDR of 0.02 or less. The TDR of the joints in the ceiling was 0.37 and the TDR of the joints in the floor was 0.79; hence, it was determined that this performance should be improved in order prevent condensation. The results of the condensation examination are valid for an indoor/outdoor temperature difference of $18.5 \pm 1.5^{\circ} \mathrm{C}$ and additional work is in progress to extend this according to the ISO 10211 method and analysis criteria. Overall, the airtightness performance should be improved by improving the joints between wall components and preventing thermal bridges (condensation). In particular, airtightness design, proper construction and installation, and the technical application of airtightness gaskets must be examined to improve the airtightness in areas where window frames, windows and window frames, and doors and door frames meet. 


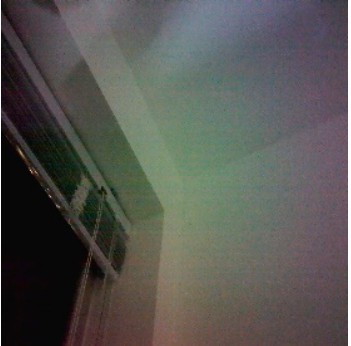

(a) Location of the second-floor ceiling corner.
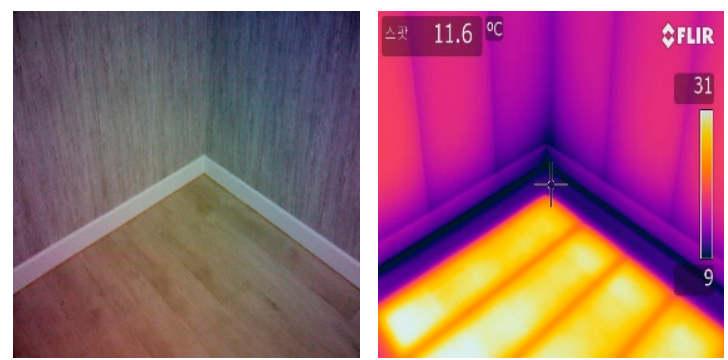

(b) Location of the first-floor bottom corner.

Figure 9. Diagnosis results of thermal bridges.

\subsection{Simulation Results}

\subsubsection{Required Heating and Cooling Loads}

Figure 10 shows the distributions of the annual outside temperature, relative humidity, and solar radiation on horizontal of the study region. The climatic conditions affect the nature of building energy consumption; hence, the design and construction of modular houses must be suitable for the actual climate. However, given that modular homes are produced in a factory then assembled locally, analysis is required to design appropriate wall fittings for each region. In this study, we investigated the heating and cooling load demands that would be generated in East Asia based on modular homes designed for energy-saving performance in Korea.

Figure 11 shows the annual required heating/cooling load based on the mock-up modular house and improved airtight performance. The annual heating/cooling energy demands for the mock-up modular house in Sapporo, which has a cold wet climate (Case 1, 12.13 1/h), was high at $1552 \mathrm{kWh} / \mathrm{m}^{2}$.year. In contrast, it was minimal in Dacca, which has a savannah climate. In Ulsan, where the climate is warm and humid, the annual heating/cooling energy requirement (Case 1, 12.13 $1 / \mathrm{h}$ ) was $1069 \mathrm{kWh} / \mathrm{m}^{2}$.year. The relationship between airtightness and the heating/cooling energy requirement according to the climate characteristics of each region shows that the energy requirements are greatly reduced when the airtight performance is reduced. 


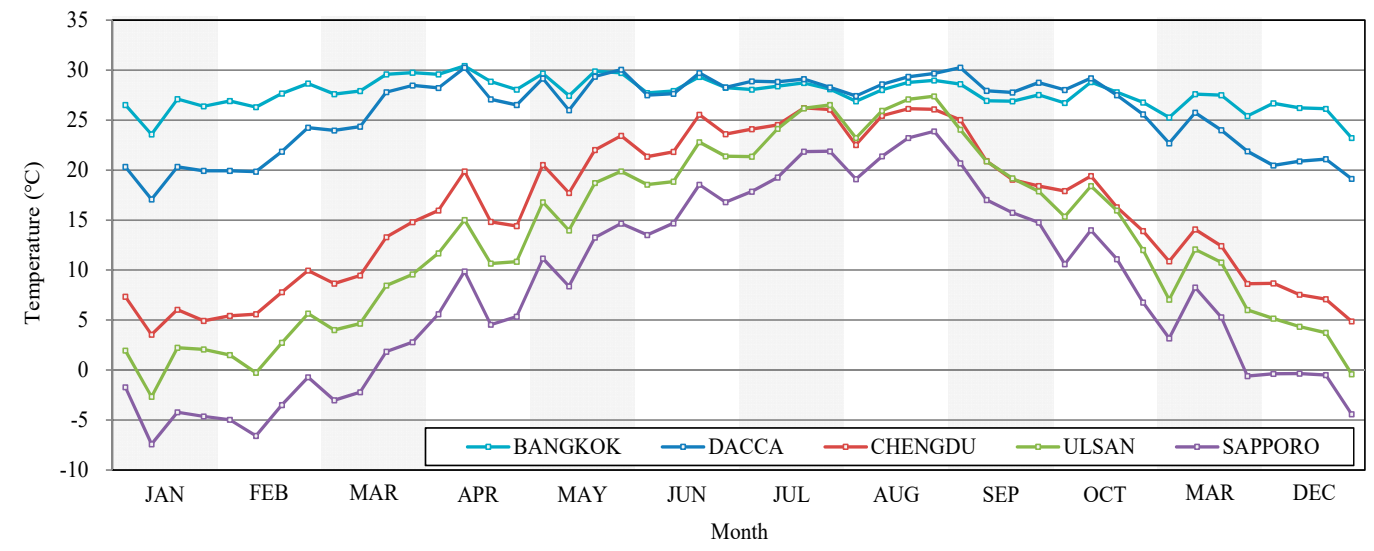

(a) Outdoor air temperature.

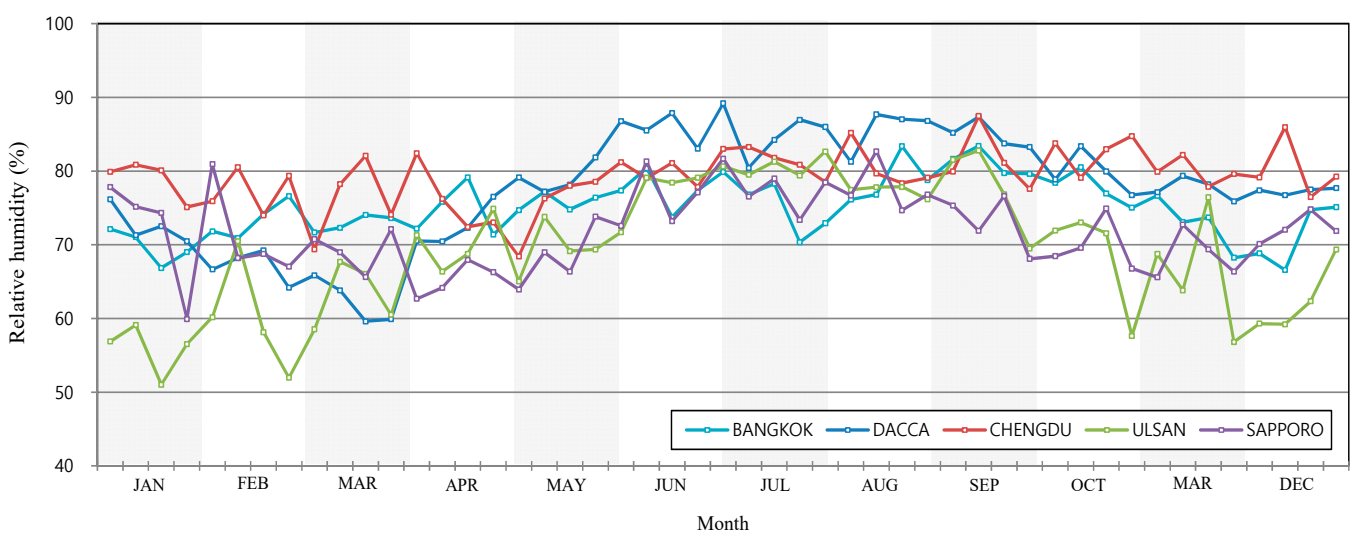

(b) Outdoor air relative humidity.

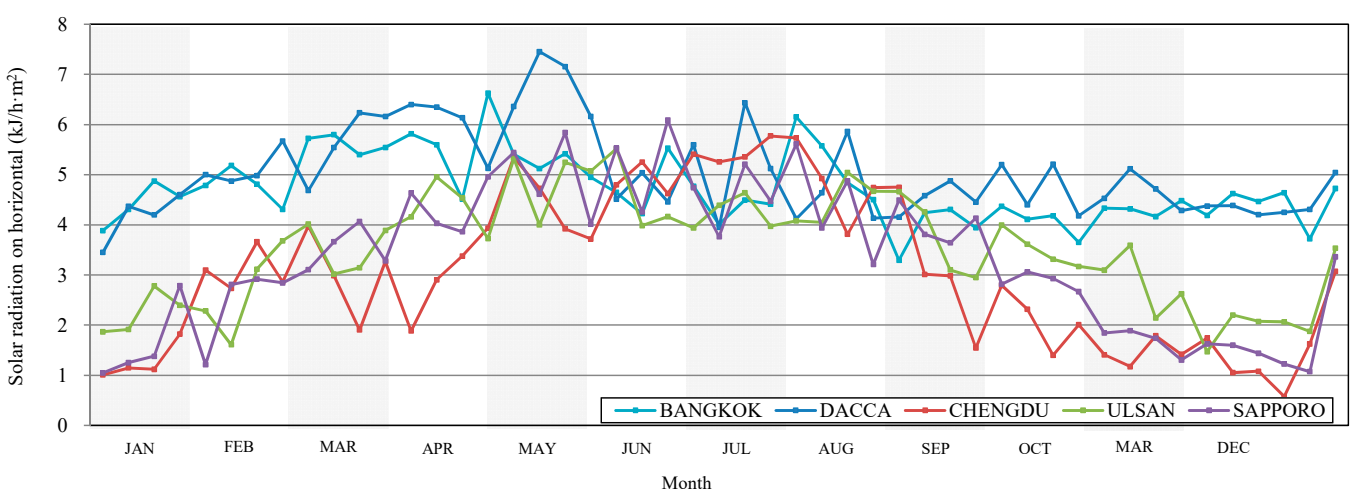

(c) Solar radiation on horizontal.

Figure 10. Average weekly outdoor air temperature, relative humidity and solar radiation on horizontal for Bangkok, Dacca, Chengdu, Ulsan, and Sapporo. 


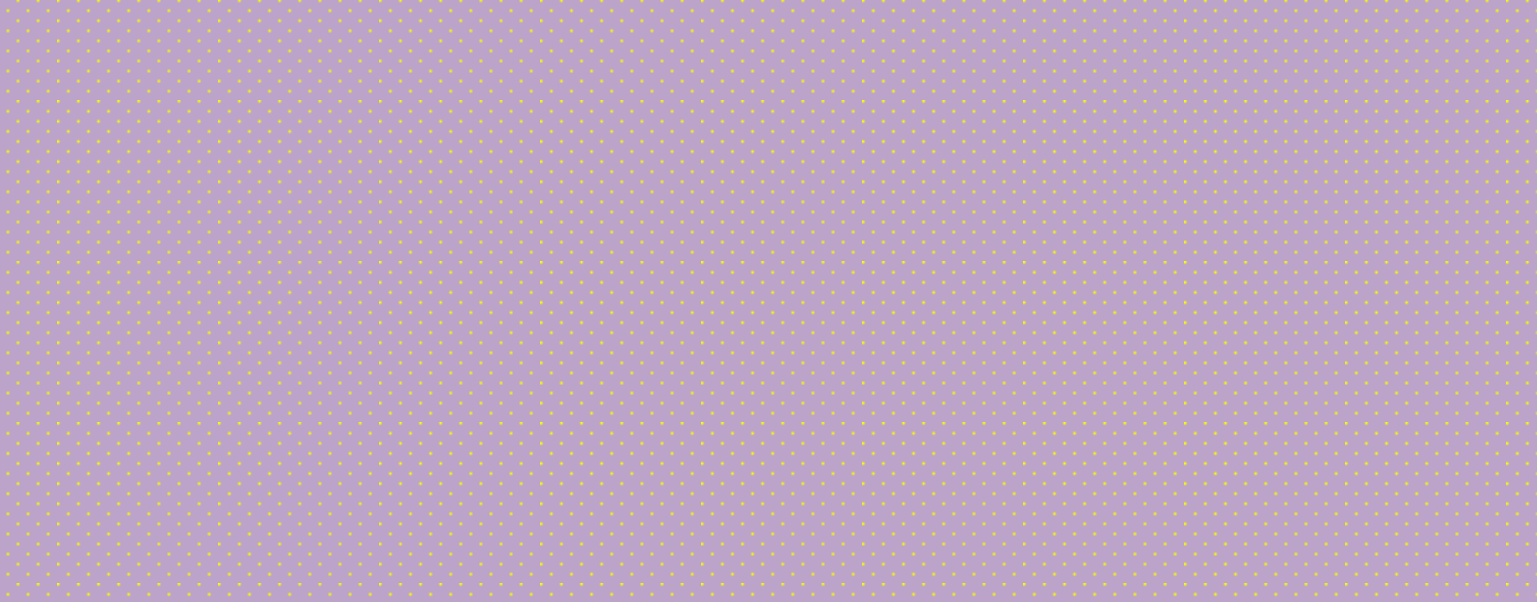

Figure 11. The simulation results of required heating/cooling loads.

\subsubsection{Solar PV Power Generation}

The PV power generation facility was intended to be installed on the outer shell of the target house for the purpose of energy independence. The conditions required for vertical installation were considered. The PV module is a crystalline module with power generation efficiency of $16 \%$. The ambient and solar conditions of the PV facility reflect the local weather data. Figure 12 shows the annual power generation per unit module. When generating power from the roof and walls in each direction, the greatest power generation was achieved when the PV unit was installed on the roof. This was followed by units on south-facing walls.

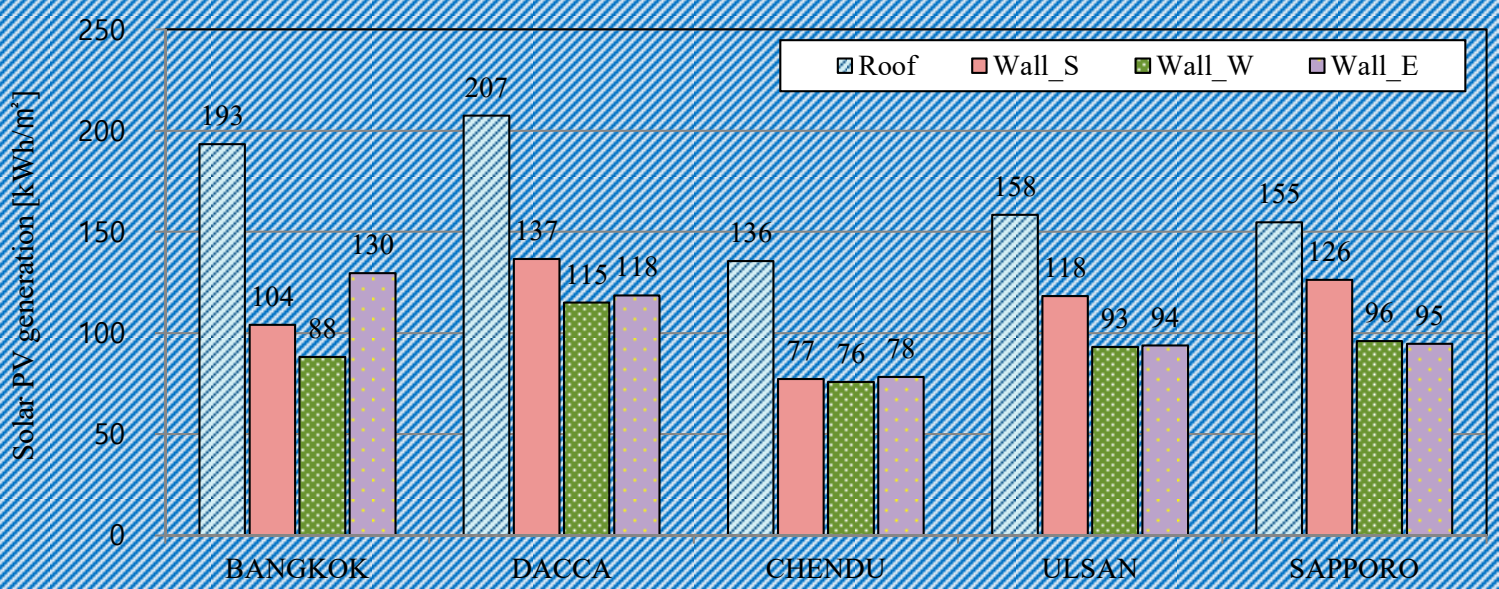

Figure 12. Solar PV generation.

\subsubsection{Energy Independence Rates}

Figure 13 shows the energy independence rate according to the heating/cooling energy requirements and PV power generation. In Section 4.2, we showed that the lowest heating/cooling loads were in Bangkok and Dacca, where there is a savannah climate and cooling loads were the main source. The energy independence rate exceeded $100 \%$ when the roof was selected as the PV unit location and airtight performance improvements were conducted. In other regions, the ability to achieve $100 \%$ energy independence was limited, even when the airtightness was improved and an appropriate location for the PV installation was selected. However, the amount of power generation is expected to vary depending on the type of solar panel and the installation method. Thus, it is necessary to consider the correct installation method and area based on characteristics such as the mobility of the modular building. Furthermore, in addition to increasing the design capacity of the PV 
unit, limiting the energy demand of the actual user will help to achieve energy independence. In the future, energy balance will be achieved through detailed load analysis in order to obtain basic data according to the design patterns.

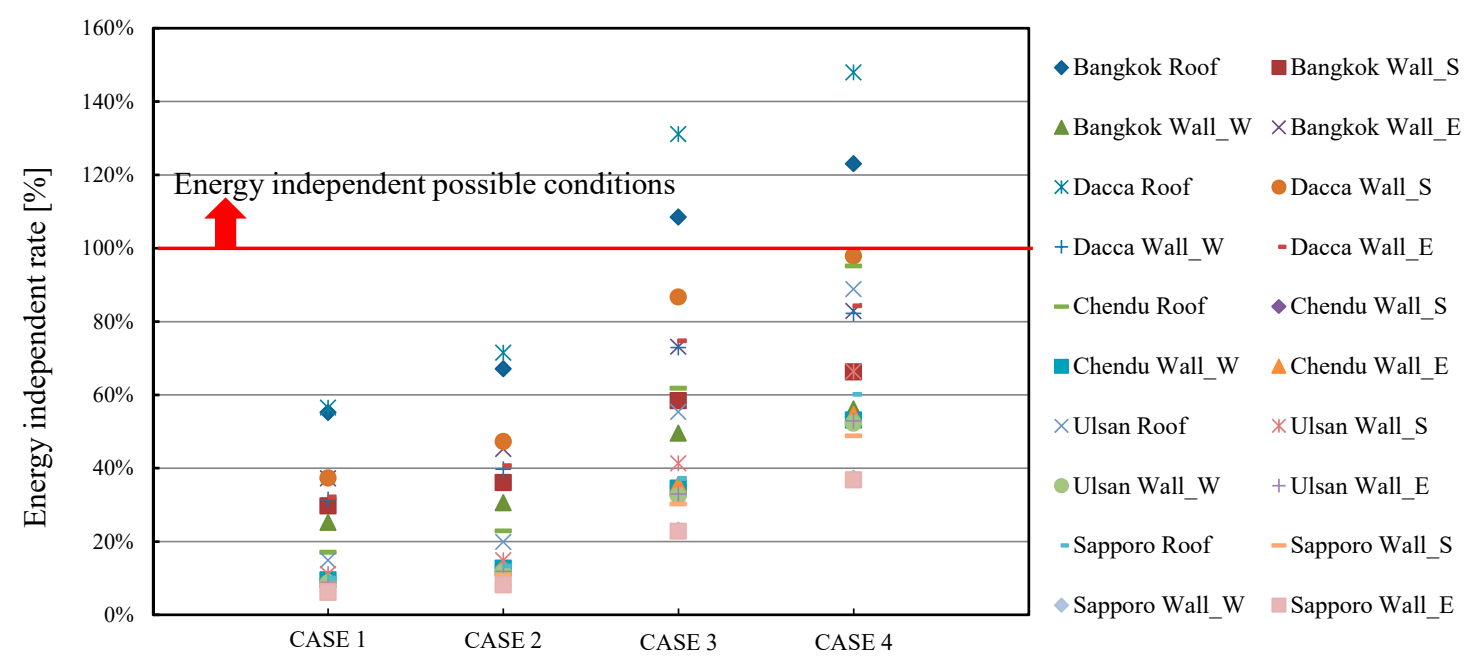

Figure 13. Energy independence rates.

\section{Conclusions}

In this study, we explored the feasibility of achieving energy independence for modular housing by reducing the airtightness and selecting an appropriate location for the PV unit. This was achieved through dynamic energy simulations. The energy independence rates were evaluated based on a mock-up of modular housing in five East Asian cities: Sapporo, Ulsan, Chengdu, Dacca, and Bangkok. From the test and simulation results, the following conclusions were made:

(1) The airtightness performance ACH50 of the mock-up modular house was $12.13 \mathrm{1} / \mathrm{h}$ and the thermal transmittance of the walls was $0.180 \mathrm{~W} /\left(\mathrm{m}^{2} \cdot \mathrm{K}\right)$, which did not satisfy the airtightness performance standards for industrialized houses. However, the thermal insulation performance (Central Region II) satisfied the required standard. To respond appropriately to a disaster situation, the technology needs to be improved to satisfy the airtightness performance standards for industrialized houses.

(2) Reducing the airtightness can reduce the annual heating/cooling load. The heating load showed the greatest reduction in the Sapporo area, which has a cold and humid climate. The relationship between airtightness reduction and the cooling/heating energy requirements varies according to the climate characteristics of each region, and the energy demand greatly decreased when the airtightness decreased.

(3) The energy generation per unit area was greatest when the PV unit was positioned with zero ceiling azimuth. Dacca and Bangkok showed the greatest power generation of all the regions. If improvements in airtightness are achieved and an appropriate aspect is selected for the PV unit, then energy independence is possible in Dacca and Bangkok if the Case $3(3.081 / \mathrm{h})$ level is improved. In addition, when the heating/cooling load was compared with the annual power generation, these regions were shown to have low heating/cooling requirements and high power generation.

In order to realize energy independence for modular structures, we intend to develop a more refined method by improving the construction. In addition, for long-term technical improvement, efforts are needed to establish quantitative standards in the design stage and to advance the technology in terms of heat bridges, airtightness, and insulation material guide books. A more detailed simulation will be conducted so that different types of solar PV units and efficient energy storage systems with power distribution can be assessed for disaster scenarios. From another point of view, we also need to 
analyze how people's energy-saving spirit affects energy independence and the residential environment in a disaster situation.

Author Contributions: Investigation, B.P.; Simulation analysis, Y.J.; Formal analysis, J.C. and Y.J.; Literature review, B.P. and Y.J.; Writing-original draft preparation, B.P.; Writing-review and editing, J.C. and Y.J.

Funding: This research was supported by a grant from the research fund of the Korea KAIA (Korea Agency for Infrastructure Technology Advancement) in 2018 (project no. 18TBIP-C144010-01).

Conflicts of Interest: The authors declare no conflict of interest.

\section{Abbreviations}

$\begin{array}{ll}\mathrm{ACH} & \text { Air change rates } \\ \mathrm{TDR} & \text { Temperature difference ratio } \\ \mathrm{T}_{\mathrm{i}} & \text { Inter air temperature }\left({ }^{\circ} \mathrm{C}\right) \\ \mathrm{T}_{\mathrm{m}} & \text { Inter wall surface temperature of external wall }\left({ }^{\circ} \mathrm{C}\right) \\ \mathrm{T}_{\mathrm{o}} & \text { Outer air temperature }\left({ }^{\circ} \mathrm{C}\right)\end{array}$

\section{References}

1. Ministry of the Interior and Safety. Disaster Year Book 2017; Ministry of the Interior and Safety: Seoul, Korea, 2018. Available online: https://www.mois.go.kr/frt/bbs/type001/commonSelectBoardArticle.do? bbsId=BBSMSTR_000000000013\&nttId=61301/ (accessed on 9 October 2019).

2. Ministry of the Interior and Safety. Statistical Yearbook of Natural Disaster 2017; Ministry of the Interior and Safety: Seoul, Korea, 2018. Available online: https://www.mois.go.kr/frt/bbs/type001/ commonSelectBoardArticle.do?bbsId=BBSMSTR_000000000013\&nttId=61301/ (accessed on 9 October 2019).

3. Basic Act on Disaster and Safety Management Law; Low No. 15764, 18. Set. 2018; Ministry of the Interior and Safety: Seoul, Korea, 2018.

4. Annan, C.-D. Applicability of Traditional Design Procedures to Modular Steel Buildings; School of Graduate and Postdoctoral Studies, University of Western Ontario: London, UK, 2008.

5. Li, H.X.; Al-Hussein, M.; Lei, Z.; Ajweh, Z. Risk identification and assessment of modular construction utilizing fuzzy analytic hierarchy process (AHP) and simulation. Can. J. Civ. Eng. 2013, 40, 1184-1195. [CrossRef]

6. Kamali, M.; Hewage, K. Life cycle performance of modular buildings: A critical review. Renew. Sustain. Energy Rev. 2016, 62, 1171-1183. [CrossRef]

7. Košir, M.; Iglič, N.; Kunič, R. Optimisation of heating, cooling and lighting energy performance of modular buildings in respect to location's climatic specifics. Renew. Energy 2018, 129, 527-539. [CrossRef]

8. Kamali, M.; Hewage, K.; Milani, A.S. Life cycle sustainability performance assessment framework for residential modular buildings: Aggregated sustainability indices. Build. Environ. 2018, 138, 21-41. [CrossRef]

9. Wang, C.; Huang, X.; Deng, S.; Long, E.; Niu, J. An experimental study on applying PCMs to disaster-relief prefabricated temporary houses for improving internal thermal environment in summer. Energy Build. 2018, 179, 301-310. [CrossRef]

10. Marin, P.; Saffari, M.; de Gracia, A.; Zhu, X.; Farid, M.M.; Cabeza, L.F.; Ushak, S. Energy savings due to the use of PCM for relocatable lightweight buildings passive heating and cooling in different weather conditions. Energy Build. 2016, 129, 274-283. [CrossRef]

11. Smith, R.E. Prefab Architecture: A Guide to Modular Design and Construction; John Wiley \& Sons: Hoboken, NJ, USA, 2010.

12. Jo, B.-H.; Lee, W.I. Global Research-Overcome Market of Modular Architecture (England). Korea Inst. Constr. Eng. Manag. 2014, 15, 53-57.

13. Kim, K.H. A Study on the Architectural Responses on the Post-disaster Refugees Housing-Especially on the Open System Modular Housing. Ph.D Thesis, Inha-University, Incheon, Korea, 2005.

14. Moon, J. A Study on the Planning Method Temporary Dwellings for Sufferers from a Disaster; Decree of the Yonsei University: Seoul, Korea, 2007.

15. Development of a Temporary Living Space Systems against Disasters; Infrastructure and Transport R\&D Report; The Ministry of Land: Seoul, Korea, 2014. 
16. Wang, W.-C.; Lim, S.-H. A Study on the Space Expansion of Temporary Housing to Utilize Modular Mock-up. J. Archit. Inst. Korea Plan. Des. 2014, 30, 103-111. [CrossRef]

17. Khan, H.; Asif, M. Impact of green roof and orientation on the energy performance of buildings: A case study from Saudi Arabia. Sustainability 2017, 9, 640. [CrossRef]

18. Al Dakheel, J.; Tabet Aoul, K. Building applications, opportunities and challenges of active shading systems: A state-of-the-art review. Energies 2017, 10, 1672. [CrossRef]

19. Aldegheri, F.; Baricordi, S.; Bernardoni, P.; Brocato, M.; Calabrese, G.; Guidi, V.; Mondardini, L.; Pozzetti, L.; Tonezzer, M.; Vincenzi, D. Building integrated low concentration solar system for a self-sustainable Mediterranean villa: The Astonyshine house. Energy Build. 2014, 77, 355-363. [CrossRef]

20. Zubair, M.; Bilal Awan, A.; Al-Ahmadi, A.; Abo-Khalil, A. NPC based design optimization for a net zero office building in hot climates with PV panels as shading device. Energies 2018, 11, 1391. [CrossRef]

21. Hex-House. Available online: http://www.hex-house.com/ (accessed on 21 July 2019).

22. Tuvie. Available online: http://www.tuvie.com/ted-transportable-emergency-dwelling/ (accessed on 21 July 2019).

23. Inhabitat. Available online: https://inhabitat.com/bellomo-architects-tiny-house-arc-prefab-home-is-nowavailable-for-order/ (accessed on 21 July 2019).

24. Inhabitat. Available online: https://inhabitat.com/a-prototype-of-the-ablenook-rapidly-deployableemergency-modular-living-unit-is-now-complete/ (accessed on 21 July 2019).

25. Inhabitat. Available online: https://inhabitat.com/ex-container-project-provides-shipping-containerhousing-for-victims-of-japan-earthquake/ (accessed on 21 July 2019).

26. Dezeen. Available online: https://www.dezeen.com/2011/07/21/multi-storey-temporary-housing-by-shigeruban-architects/ (accessed on 21 July 2019).

27. Ikea. Available online: https://www.ikea.com/ms/en_US/this-is-ikea/ikea-highlights/2017/better-shelter/ index.html (accessed on 21 July 2019).

28. Ministry of Land. Transport and Maritime Affairs; Energy Saving Building Design Standards; Ministry of Land: Seoul, Korea, 2006.

29. Standard of Construction Housing. Low No. 584. 12 Aug 2016; Ministry of the Infrastructure and Transport: Seoul, Korea, 2016.

30. Korea Agency for Technology and Standards. KS L ISO 9972 Thermal Insulation-Determination of Building Airtightness-Fan Pressurization Method; Korea Agency for Technology and Standards: Seoul, Korea, 2016.

31. Korea Agency for Technology and Standards. KS F2278 Standard Test Method for Thermal Resistance for Windows and Doors; Korea Agency for Technology and Standards: Seoul, Korea, 2017.

32. International Standards. ISO 10211 Thermal Bridges in Building Construction-Heat Flows and Surface Temperatures-Detailed Calculations; International Standards: Geneva, Switzerland, 2007.

33. Korean Institute of Architectural. Sustainable Environment and Building Systems, Building Airtightness Criteria, Appendix 2; Korean Institute of Architectural: Seoul, Korea, 2013; p. 8.

34. Johnston, D.; Miles-Shenton, D.; Bell, M.; Wingfield, J. Airtightness of Buildings-Towards Higher Performance: Final Report_-Domestic Sector Airtightness; Sheffield University: London, UK, 2011.

35. Pan, W. Relationships between air-tightness and its influencing factors of post-2006 new-build dwellings in the UK. Build. Environ. 2010, 45, 2387-2399. [CrossRef]

36. Sherman, M.H.; Chan, W.R. Building air tightness: Research and practice. In Building Ventilation; Routledge: London, UK, 2006; pp. 155-180.

37. Chan, W.R.; Nazaroff, W.W.; Price, P.N.; Sohn, M.D.; Gadgil, A.J. Analyzing a database of residential air leakage in the United States. Atmos. Environ. 2005, 39, 3445-3455. [CrossRef]

38. A Review of the Test Methods for Air-tightness Performance of Building Components Using the Blower Door System. Int. J. Air Cond. Refrig. 2019, 31, 216-226. [CrossRef]

39. Sfakianaki, A.; Pavlou, K.; Santamouris, M.; Livada, I.; Assimakopoulos, M.-N.; Mantas, P.; Christakopoulos, A. Air tightness measurements of residential houses in Athens, Greece. Build. Environ. 2008, 43, 398-405. [CrossRef]

40. Sinnott, D.; Dyer, M. Air-tightness field data for dwellings in Ireland. Build. Environ. 2012, 51, $269-275$. [CrossRef]

41. Kim, S.; Chang, Y.-S.; Park, J.-S.; Shim, K.-B. Analysis of Airtightness and Air Leakage of Wooden Houses in Korea. J. Korean Wood Sci. Technol. 2017, 45, 828-835. 
42. Kim, H.-B.; Park, J.-S.; Hong, J.-P.; Oh, J.-K.; Lee, J.-J. Air Tightness Performance of Residential Timber Frame Buildings. J. Korean Wood Sci. Technol. 2014, 42, 89-100. [CrossRef]

43. Tanyer, A.-m.; Tavukcuoglu, A.; Bekboliev, M. Assessing the airtightness performance of container house in relation to its effect on energy efficiency. Build. Environ. 2018, 134, 59-73. [CrossRef]

(C) 2019 by the authors. Licensee MDPI, Basel, Switzerland. This article is an open access article distributed under the terms and conditions of the Creative Commons Attribution (CC BY) license (http://creativecommons.org/licenses/by/4.0/). 